\title{
Correlation between oxidative stress and tumor grade in glioma cells from patients in Jakarta
}

\author{
Novi S. Hardiany, ${ }^{1}$ Wawan Mulyawan, ${ }^{2}$ Septelia I. Wanandi ${ }^{1}$ \\ ${ }^{1}$ Department of Biochemistry and Molecular Biology, Faculty of Medicine, Universitas Indonesia, Jakarta, Indonesia \\ ${ }^{2}$ Department of Neurosurgery, RUSPAU
}

\begin{abstract}
Abstrak
Latar belakang: Untuk menganalisis hubungan antara stres oksidatif pada sel glioma manusia dengan derajat keganasan, sehingga dapat mengeksplorasi peranan stress oksidatif sebagai petanda tumor dalam menentukan progresi tumor.

Metode: Sampel terdiri dari 21 jaringan tumor dan 5 jaringan otak normal dari penderita glioma. Stres oksidatif dianalisis melalui pengukuran Malondyaldehida (MDA) yang menggambarkan kerusakan lipid dan kadar karbonil untuk kerusakan protein, serta 8-hydroxy-2'-deoxyguanosinel 8-OHdG untuk kerusakan DNA. Selain itu, dilakukan analisis terhadap ekspresi Manganese Superoxide Dismutase (MnSOD) sebagai enzim antioksidan utama yang berperan dalam stres oksidatif. Ekspresi MnSOD dianalisis melalui pengukuran mRNA MnSOD menggunakan Real Time PCR dan aktivitas spesifik enzim MnSOD menggunakan inhibisi xantin oksidase (kit RanSOD). Derajat keganasan ditentukan berdasarkan pemeriksaan histopatologis. Analisis statistik dengan menggunakan t-test dan uji korelasi Pearson.
\end{abstract}

Hasil: Kadar MDA, karbonil dan 8-OHdG sebagai parameter stres oksidatif pada glioma lebih tinggi bermakna dibandingkan dengan otak normal. Kadar MDA dan karbonil ini meningkat sesuai dengan derajat keganasan. Ekspresi relatif mRNA MnSOD dan aktivitas spesisifik enzim MnSOD pada glioma lebih tinggi bermakna dibandingkan dengan otak normal. Ekspresi relatif mRNA MnSOD tersebut meningkat bermakna sesuai dengan derajat keganasan. Namun, aktivitas spesifik enzim MnSOD pada glioma derajat tinggi lebih rendah bermakna dibandingkan glioma derajat rendah, dengan demikian terdapat ketidak sesuaian antara sintesis mRNA MnSOD dengan aktivitas spesifiknya. Terdapat korelasi positif antara mRNA MnSOD dengan kadar MDA.

Kesimpulan: Kerusakan oksidatif yang terjadi pada sel glioma berhubungan bermakna dengan derajat keganasan. Tingginya mRNA dan aktivitas spesifik MnSOD pada sel glioma berhubungan dengan tingginya kerusakan oksidatif. (Med J Indones. 2012;21:122-7)

\begin{abstract}
Background: The goal of this study was to analyze the correlation of oxidative stress in human glioma cells with tumor grade in order to explore the role of oxidative stress as a marker in determining the tumor progression.

Methods: Samples were 21 brain tumors and 5 normal brain tissues from glioma patients. Oxidative stress was analyzed by measuring malondialdehyde (MDA), carbonyl and 8-hydroxy-2'-deoxyguanosine (8-OHdG). Additionaly, we analyzed MnSOD expression by measuring the MnSOD mRNA using real time RT-PCR and MnSOD enzyme activity using RanSOD kit. Tumor grade was determined by histopathologic examination. Data was statistically analyzed using t-test and Pearson correlation.

Results: Levels of MDA, carbonyl and 8-OHdG reflecting oxidative stress in glioma cells were significantly higher than in normal brain tissue. The MDA and carbonyl levels were significantly correlated with tumor grade. Relative expression of MnSOD mRNA and specific enzyme activity in glioma cells were significantly higher than in normal brain cells. The relative expression of MnSOD mRNA increased significantly in accordance with the tumor grade. Surprisingly, MnSOD specific activity was significantly lower in high grade than in low grade glioma indicating a discrepancy between mRNA synthesis and its enzyme specific activity. Furthermore, there was a positive correlation between MnSOD mRNA and MDA levels.

Conclusion: The high level of oxidative damage in human glioma cells was significantly correlated with tumor grade. The high level of MnSOD expression in human glioma cells was correlated with the high level of oxidative damage. (Med J Indones. 2012;21:122-7)
\end{abstract}

Keywords: Glioma, oxidative stress, tumor grade

Glioma is the primary brain tumor, which is frequently found in Indonesia. As malignancy in general, the causes of glioma are multifactorial. Among these factors are reactive oxygen species (ROS), molecules which contain oxygen on a higher level of reactivity than in ground state molecular oxygen. ${ }^{1}$ Low levels of ROS have the physiological function to activate and modulate signal transduction pathways, to modulate the activity of redox-sensitive transcription factors and to regulate the activity of mitochondrial enzymes. ${ }^{1,2}$ High levels of ROS are toxic for the cells due to oxidative stress induction. ${ }^{1}$ Oxidative stress can induce oxidative damage to molecules in the cells like protein, lipid and deoxyribonucleic acid (DNA). ${ }^{1}$ DNA damage can induce genomic instability, which influences cancer progression. Therefore, ROS are important for initiation, progression and defense of cancer cells. ${ }^{3}$ 
Our bodies have a protection system of endogenous antioxidant enzymes to overcome the oxidative stress. One of them is manganese superoxide dismutase (MnSOD), which is located in mitochondria of all cells as the major antioxidant enzyme that scavenges superoxide radicals, which are produced by the mitochondrial electron transport chain. MnSOD catalyzes the conversion of $\mathrm{O}_{2} \cdot$ to oxygen $\left(\mathrm{O}_{2}\right)$ and hydrogen peroxide $\left(\mathrm{H}_{2} \mathrm{O}_{2}\right) \cdot{ }^{1}$ Decreased MnSOD levels may elevate ROS level in mitochondria leading to oxidative stress, i.e., oxidative damage of biomacromolecules and subcellular structures. For the past 20 years, MnSOD activity has been postulated to be low in malignant tumours. A previous study of our group $^{4}$ on MnSOD expression showed that in $70 \%$ sample distribution of glioma cells, mRNA MnSOD was significantly lower than in leucocytes as control. In $80 \%$ sample distribution of glioma cells, the specific enzyme activity of MnSOD was significantly lower than in leucocytes as control. We found a linear relationship between MnSOD mRNA and specific enzyme activity with moderate correlation and statistical significance. ${ }^{4}$

Tumor cells generate superoxide radical and other ROS, which might affect proliferation and invasion. It has been hypothesized that the production of ROS combined with a decreased level of antioxidant enzymes may be characteristic of tumour cells. ${ }^{3}$ Ganesamoni et al. ${ }^{5}$ and Bancell et al. ${ }^{6}$ proved that oxidative stress was higher in cancer cells than in normal cells. In breast and gastric cancers, high levels of ROS were associated with tumor progression and metastasis risk..$^{5-7}$ Based on WHO classification using histopathological examination, glioma can be divided into low grade and high grade. However, this classification cannot be the only prognostic indicator for the success of radiotherapy, since in the group with the same degree of malignancy the response to extensive radiotherapy widely varies. Renindra et al. ${ }^{8}$ found that in low grade glioma, tumor size reduction after radiotherapy varied between $10 \%$ and $70 \%$ and in high grade tumors between $30 \%$ and $70 \% .{ }^{8}$ Thus, other factors, such as oxidative stress may influence tumor progression. Regarding this problem, we wanted to analyze the correlation of oxidative stress by measuring oxidative markers and MnSOD expression as endogenous antioxidant with tumor grade in order to explore the role of oxidative stress in determining the tumor progression.

\section{METHODS}

This study was a cross sectional study carried out at Biochemistry and Molecular Biology Laboratory, Faculty of Medicine Universitas Indonesia from January 2009 until December 2010 using as subjects
21 glioma patients from three hospitals in Jakarta, RSUPAU, RSPAD and RSCM. The inclusion criteria were i) a glioma patient with ii) informed consent, who was iii) diagnosed glioma by radiology examination and iv) underwent open surgery craniotomy. The exclusion criteria were i) a subject with the result of histological examination that did not confirm glioma. Samples of glioma and normal brain cells were obtained by open surgery craniotomy, samples were stored at $-70^{\circ} \mathrm{C}$ or homogenized directly. Normal brain cells, which were used as controls could be obtained from patients if the location of glioma was below normal brain tissue. All procedures were approved by the Research and Development Committee, Faculty of Medicine Universitas Indonesia (No.409/PT.02.FK/ETIK/2008).

\section{Analysis of tumor grade}

Tumor grade was determined using histological examination. The WHO system established a four-tiered histologic grading guideline for gliomas that assigns grades from 1 to 4 , with 1 being the least aggressive and 4 being the most aggressive. Grade 1 is pilocytic astrocytoma, grade 2 is diffuse astrocytoma, grade 3 is anaplastic astrocytoma, and grade 4 is glioblastoma multiforme (GBM). Grade 1 and 2 are classified as lowgrade gliomas. Grade 3 and 4 are classified as highgrade gliomas. In this research, glioma samples were classified in low grade glioma and high grade glioma.

\section{Analysis of oxidative stress}

Malondialdehyde (MDA) reflecting lipid peroxidation was measured using thiobarbiturate test with Wills method. ${ }^{9}$ Carbonyls reflecting protein oxidation were measured using 2,4 dinitrophenylhydrazine (DNPH) reaction. ${ }^{10}$ Our third indicator of oxidative stress, 8-hydroxy-2'-deoxyguanosine (8-OHdG) reflecting DNA damage was measured with Cayman $8-\mathrm{OHdG}$ EIA $^{\circledR}$ kit. DNA was extracted from the glioma and normal brain tissues using Wizard Genomic DNA Extraction Kit (Promega ${ }^{\circledR}$ ), then DNA was digested using nuclease $\left(\right.$ Roche $^{\mathbb{R}}$ ) following manufacturer's instruction. One unit of alkaline phosphatase was added into $100 \mu \mathrm{g}$ of DNA. Cayman 8-OHdG EIA kit is a competitive assay, which utilizes an antimouse IgG-coated plate and a tracer consisting of an 8-OHdG enzyme conjugate. The product of this enzymatic reaction has a distinct yellow colour and absorbs strongly at $412 \mathrm{~nm}$.

\section{Amplification cDNA using reverse transcriptase real time PCR}

RNA was extracted from glioma tissues and normal brain tissues using Tripure RNA Isolation Kit (Roche $\left.{ }^{\circledR}\right)$. 
The step of RNA isolation followed the manufacturer's instructions. RNA hydration samples were stored at $-70^{\circ} \mathrm{C}$ until used. RNA samples (both from glioma tissues and normal brain tissues) were amplified using iScript One Step RT-PCR Kit with SYBR Green (BioRad). cDNA synthesis and PCR amplification were carried out in the same tube. Reaction protocols were: cDNA synthesis for 10 minutes at $50^{\circ} \mathrm{C}$, inactivation of iScript Reverse transcriptase for 5 minutes at $95^{\circ} \mathrm{C}$, PCR cycles (40 cycles) for 10 seconds at $95^{\circ} \mathrm{C} ; 30$ seconds at $59^{\circ} \mathrm{C}$ (optimum condition); 30 seconds at $72^{\circ} \mathrm{C}$, Melt curve analysis for 1 minutes at $95^{\circ} \mathrm{C}$; 1 minute at $55^{\circ} \mathrm{C} ; 10$ seconds at $55^{\circ} \mathrm{C}(80$ cycles, increasing $0.5^{\circ} \mathrm{C}$ each cycle). Primers for the MnSOD gene were GCACTAGCAGCATGTTGAGC (forward) and ACTTCTCCTCGGTGACGTTC (reverse) with an amplicon size of $216 \mathrm{bp}$. 18S rRNA was used as external standard wuth the same amplification procedures as for the MnSOD gene. Primers for $18 \mathrm{~S}$ rRNA were AAACGGCTACCACATCCAAG (forward) and CCTCCAATGGATCCTCGTTA (reverse) with an amplicon size of $155 \mathrm{bp}$. Primers for this reaction were designed by Primer3 programme and Primer Analysis software. Sequence for MnSOD (NM_000636) and for 18S rRNA (X03205) were obtained from NCBI Gene bank. Aquabidest was used as a negative control (NTC) to reduce false positive results. Levels of mRNA expression in glioma cells were relatively determined using PfaffI formula and normalized against normal brain cells as controls of the particular patients.

\section{The MnSOD enzyme specific activity}

Tissue samples (10-20 mg) were homogenized in $600 \mu \mathrm{L}$ Nuclei Lysis Solution, Promega ${ }^{\circledR}$ on ice and then $0.6 \mu \mathrm{L}$ PMSF solution was added to prevent protein degradation. The mixture was incubated at $65^{\circ} \mathrm{C}$ for 10 minutes. The tissue homogenates were kept at $-20^{\circ} \mathrm{C}$ before use. The MnSOD enzyme specific activity was biochemically determined using $\operatorname{RanSOD}^{\circledR}$ kit. To inhibit the $\mathrm{Cu} / \mathrm{ZnSOD}$, sodium cyanide $(5 \mathrm{mM})$ was added into each sample first and the mixture was incubated for 5 minutes at room temperature. Xanthine oxidase was then added into the mixture, followed by the measurement of light absorbance using a spectrophotometer at $505 \mathrm{~nm}$ after 30 seconds and 3 minutes. The enzyme activity was calculated as a percentage inhibition of the samples plotted to the standard curve. The specific enzyme activity of MnSOD was calculated as activity (in Units) per $\mathrm{mg}$ protein. Protein concentration was measured with a spectrophotometer at $280 \mathrm{~nm}$ and plotted to a BSA (bovine serum albumin) standard curve.

\section{Statistical analysis}

All glioma samples were compared to normal control cells. Values found in normal cells were set to 1 , values in glioma cells were expressed as ratios relative to controls and presented as mean \pm SE. Statistical significance of differences between groups was analyzed by student t-test and Pearson correlation with the significance level at $\mathrm{p}<0.05$.

\section{RESULTS}

We obtained only 5 samples of normal brain cells from glioma patients. According the WHO classification, we classified the 21 glioma samples into 15 samples of low grade glioma and 6 samples of high grade glioma. Oxidative stress parameters MDA, carbonyl and $8-\mathrm{OHdG}$ were significantly higher in glioma than in normal brain cells (Figure 1). MDA level in glioma

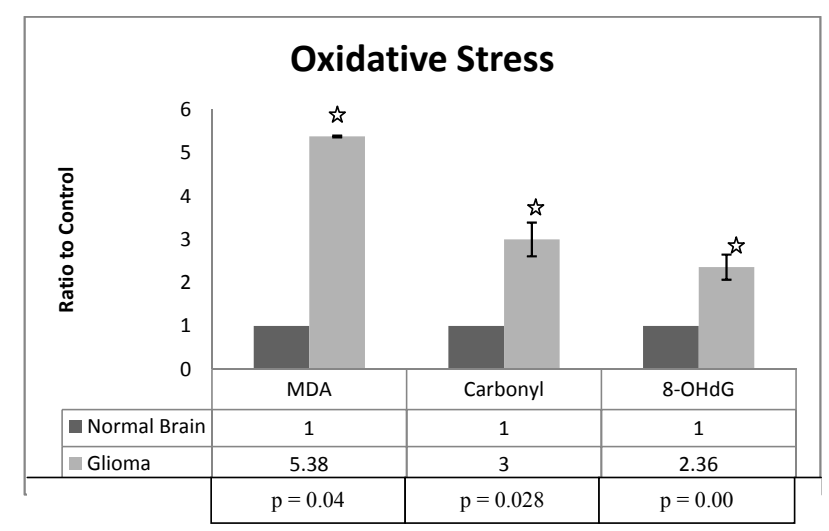

Figure 1. MDA, carbonyl and 8-OHdG levels in human glioma cells were significantly higher $(p<0.05, S E M D A \pm$ 0.02, SE carbonyl $\pm 0.39, S E 8-O H d G \pm 0.29)$ than in normal brain

was 5.38 times higher $(\mathrm{SE} \pm 0.02 ; \mathrm{p}=0.04)$ than in normal brain and increased in accordance with tumor grade (Figure 2). Carbonyl level in glioma was 3 times higher ( $\mathrm{SE} \pm 0.39 ; \mathrm{p}=0.028)$ than in normal brain and increased in accordance with tumor grade (Figure 2). Although 8-OHdG level was 2.36 times higher ( $\mathrm{SE} \pm$ $0.29 ; \mathrm{p}=0.00)$ in glioma than in normal brain, there was no significant difference $(\mathrm{p}=0.164)$ between high grade and low grade glioma (Figure 2).

Expression of MnSOD mRNA and specific enzyme activity of MnSOD were both higher in glioma than in control (Figure 3). Classification of MnSOD expression based on tumor grade (Figure 4) showed that MnSOD mRNA significantly increased in accordance with tumor grade. However, the specific enzyme activity of 


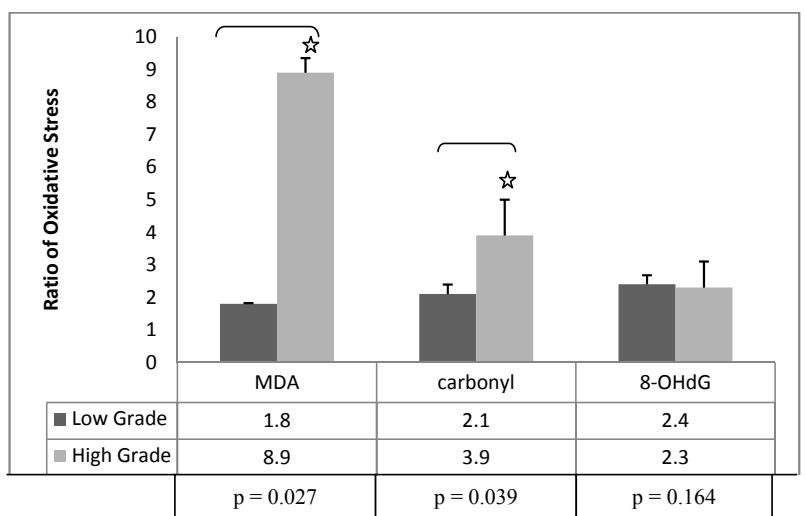

Figure 2. MDA and carbonyl levels were significantly higher ( $p$ $<0.05, S E M D A \pm 0.45, S E$ carbonyl \pm 1.1$)$ in high grade than in low grade glioma

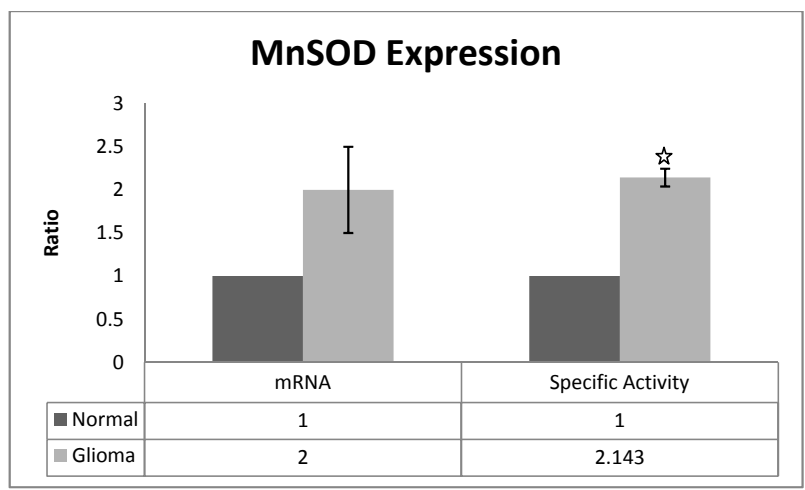

Figure 3. Relative expression of MnSOD. MnSOD mRNA was two-fold higher $(S E \pm 0.5 ; p>0.05)$ in glioma cells than in normal brain. Specific enzyme activity of MnSOD was significantly higher $(2.143 \pm 0.103 ; p<0.05)$ in glioma cells than in normal brain

MnSOD was significantly lower in high grade glioma compared with low grade glioma. Hence, there was a discrepancy between MnSOD mRNA and specific enzyme activity in high grade glioma. There was a significant positive correlation $(\mathrm{R}=0.7 ; \mathrm{p}=0.032)$ between MnSOD mRNA and MDA level.

\section{DISCUSSION}

We had only 5 samples of normal brain cells from glioma patients, because they could only be obtained if tumor was located below normal brain tissue, which is not the case in every glioma patient. Cobbs et al. ${ }^{11}$ used only 3 samples of normal brain for their research compared with 42 samples of human central nervous system tumors. ${ }^{11}$ Therefore, our comparison of 5 normal controls and 21 glioma samples could be accepted statistically.

The levels of MDA, carbonyl and 8-OHdG reflecting oxidative stress in human glioma cells were significantly higher than in normal brain. MDA is low molecular weight aldehyde that can be produced from free radical

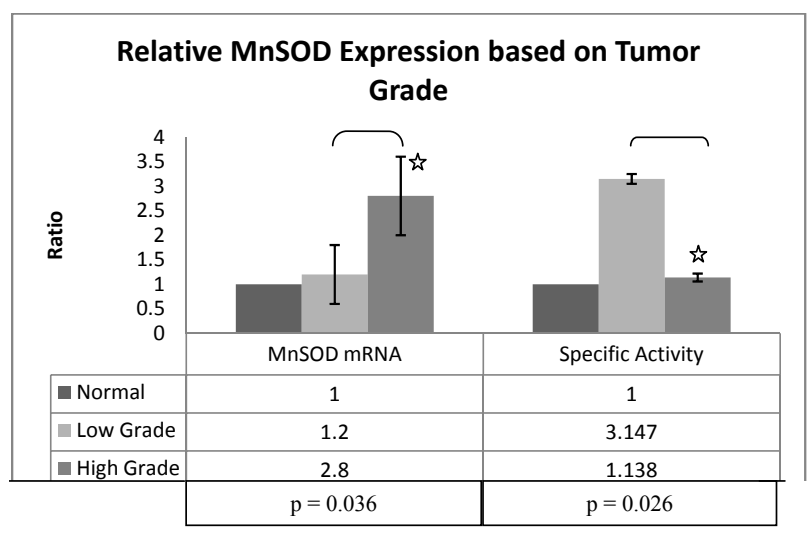

Figure 4. Relative expression of MnSOD based on tumour grade. MnSOD mRNA was significantly increased based on tumour grade (2.8 vs. 1.2, $S E \pm 0.8 ; p<0.05)$. Surprisingly, MnSOD specific activity was significantly lower in high grade than in low grade glioma (1.138 vs. 3.147, $S E \pm 0.08 ; p<0.05$ )

attack on polyunsaturated fatty acids. Increased MDA levels have been reported in many cancer types. Gonenc et al. found that average MDA levels in breast cancer patients and in lung cancer patients were higher than in normal tissue. ${ }^{12}$ Additionally, Yilmaz et al. found that mean serum MDA levels were significantly higher for both, glial and meningiomal tumor cases when compared to controls. ${ }^{13}$ Our study found that MDA level in human glioma increased in accordance with tumour grade. Similarly, elevated lipid peroxide concentrations were found in the tissues of all breast cancer patients with increasing TNM stage. ${ }^{14}$

Proteins are major targets for reactive oxidants in the cells. Protein carbonyl content is the most commonly used marker of protein oxidation. ${ }^{15}$ Our study found that carbonyl levels were significantly higher in glioma cells compared with normal brain. Similarly, increased protein carbonyl levels were found in colorectal cancer and brain tumors. ${ }^{16,17}$ Giacomo et al. found that the carbonyl level was positively associated with the progression of colorectal cancer. ${ }^{18}$ Likewise, we found carbonyl levels in human glioma cells increased in accordance with tumour grade. According to Ahmad et al. ${ }^{19}$ plasma MDA and protein carbonyl appear to reflect the oxidative stress status and disease progression in chronic myeloid leukemia and can be used as biomarkers for oxidative stress and disease progression. ${ }^{19}$

Reactive oxygen species (ROS) can induce DNA damage, i.e., base modification, free base sites (apurinic and apyrimidic), strand breakage and DNAprotein cross linking. An oxidation product detected in genomic DNA of mammalian cells is 8-hydroxy2-deoxyguanosine $(8-\mathrm{OHdG}){ }^{20}$ In our results, 8-hydroxy-2-deoxyguanosine (8-OHdG) levels were 
significantly higher in human glioma cells compared with normal brain. Tuzgen et al. ${ }^{21}$ found that $8-\mathrm{OHdG}$ was significantly higher in glioblastoma multiforme (GBM / high grade glioma) tissue ( $74.9 \mathrm{ng} / \mathrm{g}$ wet tissue) compared with control (34.71 ng/g wet tissue).

The values of MnSOD mRNA and specific enzyme activity of each glioma sample were compared with the values from normal brain cells as control, therefore the values of glioma samples are relative expression (ratio) with value "1" for control. Other studies also find higher MnSOD expression in many human cancers, the level of MnSOD directly correlates with the grade of some tumors, and high MnSOD is associated with poor prognosis in some tumors. The lower MnSOD specific activity in high grade than in low grade glioma in our study must be seen in the context with the redox state of the cells. Low antioxidant capacity and oxidant-antioxidant imbalance have been considered to play a role in multistage carcinogenesis. ${ }^{3}$ Sinha et al. ${ }^{14}$ found that increased levels of free radicals and low levels of antioxidants were observed in malignant tissues. Their study suggests that free radical activity is enhanced in breast cancer patients while the antioxidant defense mechanisms are weakened. ${ }^{14}$

High grade glioma in this research probably produced high levels of reactive oxygen species (ROS) because there were increased levels of oxidative stress biomarkers (MDA, carbonyl and 8-OHdG). MnSOD as antioxidant has the function to reduce ROS, so the lowered activity of MnSOD in high grade glioma may have been caused by consumption of this enzyme. Discrepancy between mRNA level and MnSOD specific activity was also found in breast cancer cell line T47D. ${ }^{22}$

Our research found that there was a significantly strong positive correlation between MnSOD mRNA and MDA concentration. This means that expression of MnSOD was increased when oxidative stress occurs as a cellular regulation process. Therefore, oxidative stress levels and MnSOD expression can possibly be used as indicators of glioma tumor progression.

In conclusion, the high level of oxidative damage in human glioma cells was significantly correlated with tumor grade. The high levels of MnSOD mRNA and specific enzyme activity in human glioma cells were correlated with the high level of oxidative damage. Further research is needed to analyze MnSOD protein, apoptosis and cell proliferation in glioma samples.

\section{Acknowledgment}

This work was funded by Riset Pembinaan Ilmu Pengetahuan Teknologi \& Kedokteran (RISBIN IPTEKDOK) 2009. The authors would like to thank to dr. Wismadji Sadewo, SpBS (RSCM); dr.Syaiful, SpBS (RSCM) and dr. Yudi SpBS (RUSPAU) for kindly helping us to collect the samples from glioma patients.

\section{REFERENCES}

1. Halliwell B, Gutteridge JMC. Free radical in biology and medicine. 4th ed. London: Oxford University Press; 2007. p.30-74.

2. Monteiro HP, Stern A. Redox modulation of tyrosine phosphorylation-dependent signal transduction pathways. Free Radic Biol Med. 1996;21:323-33.

3. Halliwell B. Oxidative stress and cancer: have we moved forward?. Biochem J. 2007; 401; 1-11.

4. Hardiany NS, Sadikin M, Wanandi SI. Gene expression of manganese superoxide dismutase (MnSOD) in human glioma cells. Med J Indones. 2010;19(1):21-5.

5. Ganesamoni R, Bhattacharyya S, Kumar S, Chauhan A, Mete UK, Agarwal MM et al. Status of oxidative stress in patients with renal cell carcinoma. J Urology. 2011; 187(4): 1172-6.

6. Bancel B, Esteve J, Souquet JC, Toyokuni S, Ohshima H, Pignatelli B. Differences in oxidative stress dependence between gastric adenocarcinoma subtypes. World $\mathrm{J}$ Gastroenterol. 2006; 12(7): 1005-12.

7. Brown NS, Bicknell R. Hypoxia and oxidative stress in breast cancer. Oxidative stress: its effects on the growth, metastatic potential and response to therapy of breast cancer. Breast Cancer Res. 2001; 3: 323-7.

8. Aman RA. Identifikasi faktor prediksi radiosensitivitas tumor sel glia: tinjauan khusus pada angiogenesis, proliferasi sel dan apoptosis sebagai perangai biologik tumor. [Disertasi]. Jakarta: Fakultas Kedokteran Universitas Indonesia; 2008.

9. Wills ED. Evaluation of lipid peroxidation in lipids and biological membranes. In: Snell K and Mullock B editors. Biochemical Toxicology. Washington, DC: IRL Press, 1987; p. 127-52.

10. Amici A, Levine RL, Tsai L, Stadtman ER. Conversion of amino acid residues in proteins and amino acids homopolymers to carbonyl derivatives by metal-catalyzed oxidation reactions. J Biol Chem. 1989:264; 3341-6.

11. Cobbs CS, Levi DS, Aldape K, Israel MA. Manganese superoxide dismutase expression in human central nervous system tumours. Cancer Res. 1996;56:3192-5.

12. Gonenc A, Ozkan Y, Torun M, Simsek B. Plasma malondialdehyde (MDA) levels in breast and lung cancer patients. J Clin Pharm Ther. 2001;26(2):141-2.

13. Yilmaz N, Dulger H, Kiymaz N, Yilmaz C, Bayram I, Ragip B, et al. Lipid peroxidation in patients with brain tumor. Int J Neurosci. 2006;116(8):937-43.

14. Sinha RJ, Singh R, Mehrotra S, Singh SK. Implication of free radical and antioxidant levels in carcinoma of the breast: a never-ending battle for survival. Indian J Cancer. 2009;46(2):146-50.

15. Dalle-Donne I, Rossi R, Giustarini D, Milzani A, Colombo R. Protein carbonyl groups as biomarkers of oxidative stress. Clin Chim Acta. 2003;329:23-38. 
16. Yeh CC, Lai CY, Hsieh LL, Tang R, Wu FY, Sung FC. Protein carbonyl levels, glutathione S-transferase polymorphisms and risk of colorectal cancer. Carcinogenesis. 2010;31(2):228-33.

17. Rao GM, Rakesh M, Ramesh, Sameer, Sreekantha. Study of protein oxidation products and antioxidants status in primary brain tumor patients. Int J Pharm Bio Sci. 2011;2(1):256-61

18. Di Giacomo C, Acquaviva R, Lanteri R, Licata F, Licata A, Vanella A. Nonproteic antioxidant status in plasma of subjects with colon cancer. Exp Biol Med (Maywood). 2003;228;525-8.

19. Ahmad R, Tripathi AK, Tripathi P, Singh S, Singh R, Singh RK. Malondialdehyde and protein carbonyl as biomarkers for oxidative stress and disease progression in patients with chronic myeloid leukemia. In Vivo. 2008;22:525-8.

20. Cadet J, Douki T, Frelon S, Sauvaigo S, Pauget JP, Ravanat JR. Assessment of oxidative base damage to isolated and cellular DNA by HPLC-MS/MS measurement. Free Radic Biol Med. 2002;33:441-9.

21. Tuzgen S, Hanimoglu H, Tanriverdi T, Kacira T, Sanus GZ, Atukeren P, et al. Relationship between DNA damage and total antioxidant capacity in patients with glioblastoma multiforme. Clin Oncol. 2007;19(3):177-81.

22. Wanandi SI. Up-regulation of MnSOD expression in Breast Cancer Stem Cells. Poster Presentation International Congress on Stem Cell Research, Berlin. 2011. 